JURNAL PENDIDIKAN, p-ISSN 2715-095X, e-ISSN 2686-5041

Volume 29, No.3, Nopember 2020 (305-312)

Online: http://journal.univetbantara.ac.id/index.php/jp

\title{
Penerapan Model Pembelajaran Kooperatif Tipe STAD sebagai Upaya untuk Meningkatkan Prestasi Belajar Seni Budaya dan Kesenian (SBK)
}

\author{
Suratmi \\ Guru SMP Negeri 7 Sukoharjo, Email: Suratmi38@gmail.com
}

\begin{abstract}
Abstrak: Tujuan penelitian tindakan kelas ini adalah untuk meningkatkan prestasi belajar SBK melalui model pembelajaran kooperatif tipe Student Teams Achievement Division (STAD) pada siswa kelas VIII B Semester 2 SMP Negeri 7 Sukoharjo tahun pelajaran 2017/ 2018. Penelitian ini dilaksanakan pada bulan Januari sampai Mei 2018 di SMP Negeri 7 Sukoharjo. Subjek penelitian ini adalah siswa kelas VIII B sebanyak 32 siswa. Penelitian Tindakan Kelas ini dilakukan dalam dua siklus. Teknik pengumpulan data menggunakan teknik dokumentasi, observasi, dan tes tertulis. Alat pengumpulan data berupa lembar pengamatan, butir soal tes, dan dokumen daftar nilai. Analisis data menggunakan analisis deskriptif komparatif yang dilanjutkan refleksi. Setiap siklus terdiri dari empat langkah, yaitu: (1) Perencanaan, (2) Pelaksanaan Tindakan, (3) Pengamatan, dan (4) Refleksi. Hasil penelitian menunjukkan adanya peningkatan prestasi belajar siswa, persentase ketuntasan belajar siswa, yaitu: sebelum tindakan 17 siswa atau 53,1\%, pada siklus I sebanyak 23 siswa atau 71,8\% dan pada siklus II sebanyak 217 siswa atau 90,6\%. Sedangkan rata-rata prestasi belajar SBK siswa sebelum tindakan sebesar 70,1, pada siklus I sebesar 75,2, dan pada siklus II sebesar 80. Sehingga dapat disimpulkan bahwa "Model pembelajaran kooperatif tipe STAD dapat meningkatkan prestasi belajar SBK pada siswa kelas VIII B Semester 2 SMP Negeri 7 Sukoharjo tahun pelajaran 2017/2018".
\end{abstract}

Kata-kata kunci: Prestasi Belajar SBK, Model Pembelajaran kooperatif tipe STAD

\section{The Application of Cooperative Learning Type STAD to Improve The Achievement of Art Lesson}

\author{
Suratmi \\ The Teacher of SMP Negeri 7 Sukoharjo,Email: Suratmi38@gmail.com
}

\begin{abstract}
The purpose of this classroom action research is to improve students' learning achievement of Art lesson through learning model of STAD in grade VIII B students of Semester II of SMP Negeri 7 Sukoharjo in the 2017/ 2018 school year. This research was conducted from January to May 2017 in SMP Negeri 7 Sukoharjo. The subjects of this study were students of class VIII B as many as 32 students. This research is a Classroom Action Research conducted in two cycles. Data collection techniques used documentation, observation, and written tests. Data collection tools are observation sheets, test items, and value list documents. Data analysis using comparative descriptive analysis is followed by reflection on each cycle consists of four steps, namely: (1) Planning, (2) Action Implementation, (3) Observation, and (4) Reflection. The results of this study indicate an increase in learning achievement of Art lessonstudents. This can be seen from the average score of learning achievement of Art lesson students also experienced an increase before the action of 70.1, in the first cycle of 75.2 and on the second cycle of 80 . In addition, the percentage of students' learning mastery, example before the action of $53.1 \%$, in the first cycle of $71.8 \%$ and in the second cycle of $90.6 \%$. So it can be concluded that "Cooperative learning model of STAD can
\end{abstract}


improve the learning achievement of Art lesson students of class VIII B Semester IISMP Negeri 7 Sukoharjo in 2017/2018 academic year".

Keywords: Learning Achievement of Art lesson, Learning Model of STAD

\section{Pendahuluan}

SBK identik dengan pembelajaran yang sulit dipelajari dan kurang disenangi, serta masih banyak siswa yang mengalami kesulitan dalam mempelajari SBK khususnya pada pokok bahasan Penyajian Musik.Dalam mata pembelajaranSBK, supaya materi yang disampaikan dapat diterima dan dikuasai oleh siswabiasanya dilakukan dengan memberikan soal-soal tentang Penyajian Musik. Konsep yang diajarkan dikelas kurang dipahami oleh siswa, sehingga kemampuan siswa dalam memahami materi SBK masih kurang, ini menjadikan siswa malas belajar SBK. Hal tersebut juga terjadi pada siswa kelas VIII BSMP Negeri 7 Sukoharjo, hasil ulangan harian bidang studi SBKpada siswa tersebut masih sangat rendah yaitu rata-rata kelas sebesar 70,1. Sedangkan batas ketuntasan minimalnya adalah 75,00. Dari 32 siswa, hanya 17 siswa yang nilainya di atas KKM atau hanya $53,1 \%$, sedangkan $71,8 \%$ lainnya tidak dapat melampaui maupun mencapai KKM.

Hal tersebut juga disebabkan karena kurangnya penguasaan materi siswa mengenai materi ulangan harian yang diberikan oleh guru, karena baru 53,1\%siswa yang dianggap mampu menguasai materi tersebut. Prestasi adalah hasil dari suatu kegiatan yang telah dikerjakan, diciptakan baik secara individual maupun kelompok dan prestasi belajar adalah hasil yang dicapai sebaik-baiknya menurut kemampuan anak pada waktu tertentu terhadap hal-hal yang dikerjakan atau dilakukan. (Hamdani, 2011: 137). Jadi prestasi belajar adalah hasil belajar yang telah dicapai menurut kemampuan yang tidak dimiliki dan ditandai dengan perkembangan serta perubahan tingkah laku pada diri seseorang dalam waktu tertentu. Prestasi belajar dapat dijadikan sebagai tolok ukur dari kemampuan siswa di dalam proses pembelajaran.

Prestasi belajar ini dapat dinyatakan dalam bentuk nilai dan hasil tes atau ujian. Oleh sebab itu, untuk meningkatkan penguasaan materi, rata-rata kelas dan persentase ketuntasan siswa akan digunakan model pembelajaran yang menarik dan dapat memicu peningkatan pemahaman siswa, yaitu model pembelajaran kooperatif tipe Student Teams Achievement Division(STAD). Pada dasarnya pembelajaran kooperatif tipe STAD adalah model pembelajaran yang dapat menciptakan suasana kelas menjadi menarik dan menyenangkan karena setiap kelompok yang dapat menjawab benar maka siswa tersebut akan mendapat reward. Dalam pembelajaran ini siswa harus dapat mengembangkan keterampilan dan pemahaman materi SBK untuk menerapkannya dalam kehidupan seharihari.

STAD adalah salah satu model pembelajaran yang mendorong siswa untuk ikut kooperatif dalam belajar. Dengan model pembelajaran STAD diharapkan dapat melatih kerja sama dalam menyelesaikan masalah dengan pembentukan kelompok, pembelajarannya menarik dan menyenangkan serta mendorong siswa untuk terjun kedalamnya, tidak monoton sehingga suasana tidak menegangkan serta siswa lebih semangat belajar karena suasana pembelajaran berlangsung menyenangkan sehingga mampu membantu siswa dalam meraih nilai yang tinggi. Menurut Suprijono (2009: 54) pembelajaran kooperatif sesuai dengan fitrah manusia sebagai makhluk sosial yang penuh ketergantungan dengan orang lain, mempunyai tujuan dan tanggung jawab bersama, pemberian tugas dan rasa senasib. Dengan memanfaatkan kenyataan itu, belajar kelompok 
secara kooperatif siswa dilatih dan dibiasakan bertukar pengetahuan, tanggung jawab, saling membantu dan berlatih berinteraksi-komunikasi-sosialisasi karena pembelajaran kooperatif adalah miniatur dari hidup bermasyarakat, dan belajar menyadari kekurangan dan kelebihannya masing-masing. Pembelajaran Kooperatif merupakan strategi belajar dengan sejumlah siswa sebagai anggota kelompok kecil yang tingkat kemampuannya berbeda.

Dalam menyelesaikan tugas kelompoknya, setiap siswa anggota kelompok harus saling bekerja sama dan saling membantu untuk memahami materi pembelajaran. Menurut Isjoni (2007:12) menyatakan bahwa dalam pembelajaran kooperatif, belajar dikatakan belum selesai jika salah satu teman dalam kelompok belum menguasai bahan pembelajaran. STAD adalah Pembagian Pencapaian Tim Siswa yang merupakan salah satu model pembelajaran kooperatif yang paling sederhana, dan merupakan model yang paling baik untuk permulaan bagi para guru yang baru menggunakan pendekatan kooperatif (dalam Slavin 2005: 143). Pembelajaran kooperatif tipe STAD ini merupakan salah satu tipe dari pembelajaran kooperatif dengan menggunakan kelompok-kelompok kecil dengan anggota tiap kelompok 4-5 orang siswa secara heterogen. Diawali dengan penyampaian tujuan pembelajaran, penyampaian materi, kegiatan kelompok, kuis dan penghargaan kelompok.

Menurut Slavin juga menyatakan bahwa pada STAD siswa ditempatkan dalam tim belajar beranggotakan 4-5 orang yang merupakan campuran menurut tingkat prestasi, jenis kelamin dan suku. Guru menyajikan pembelajaran, dan kemudian siswa bekerja dalam tim mereka memastikan bahwa seluruh anggota tim telah menguasai pembelajarantersebut. Kemudian, seluruh siswa diberikan tes tentang materi tersebut, pada saat tes ini mereka tidak diperbolehkan saling membantu.

Ada persiapan-persiapan yang dibutuhkan sebelum melaksanakan kegiatan pembelajaran kooperatif tipe STAD, antara lain : (1) Perangkat Pembelajaran, sebelum melaksanakan kegiatan pembelajaran ini perlu dipersiapkan perangkat pembelajarannya, yang meliputi Rencana Pelaksanaan Pembelajaran (RPP), Lembar Kerja Siswa (LKS) beserta lembar jawabannya; (2) Membentuk Kelompok Kooperatif, menentukan anggota kalompok diusahakan agar kemampuan siswa dalam kelompok adalah hiterogen dan kemampuan antar satu kelompok dengan kelompok lainnya relatif homogen. Apabila memungkinkan kelompok kooperatif perlu memperhatikan ras, agama, jenis kelamin dan latar belakang sosial. Apabila dalam kelas terdiri atas ras dan latar belakang yang relatif sama, maka pembentukan kelompok dapat didasarkan pada prestasi akademik; (3) Menentukan Skor Awal, skor awal yang dapat digunakan dalam kelas kooperatif adalah nilai ulangan sebelumnya. Skor awal ini dapat berubah setelah ada kuis. Misalnya pada pembelajaran lebih lanjut dan setelah diadakan test, maka hasil test masing-masing individu dapat dijadikan skor; (4) Pengaturan Tempat Duduk, pengaturan tempat duduk dalam kelas kooperaitif perlu juga diatur dengan baik, hal ini dilakukan untuk menunjang keberhasilan pembelajaran kooperatif apabila tidak ada pengaturan tempat duduk dapat menimbulkan kekacauan yang menyebabkan gagalnya pembelajaran pada kelas kooperatif; (5) Kerja Kelompok, untuk mencegah adanya hambatan pada pembelajaran kooperatif tipe STAD, terlebih dahulu diadakan latihan kerja sama kelompok. Hal ini bertujuan untuk lebih jauh mengenalkan masing-masing individu dalam kelompok.

Langkah-langkah pembelajaran kooperatif tipe STAD ini didasarkan pada langkahlangkah kooperatif yang terdiri atas 6 langkah atau fase. Fase-fase dalam pembelajaran ini seperti disajikan dalam tabel berikut. 
Tabel 1. Fase-fase Pembelajaran Kooperatif Tipe STAD

\begin{tabular}{|c|c|}
\hline Fase & Kegiatan Guru \\
\hline \multicolumn{2}{|l|}{ Fase 1} \\
\hline Menyampaikan tujuan dan memotivasi siswa & $\begin{array}{l}\text { Menyampaikan semua tujuan } \\
\text { pembelajaran yang ingin dicapai pada } \\
\text { pembelajaran tersebut dan memotivasi } \\
\text { siswa belajar. }\end{array}$ \\
\hline \multicolumn{2}{|r|}{ siswa ouragar. } \\
\hline Menyajikan/menyampaikan informasi & $\begin{array}{l}\text { Menyajikan informasi kepada siswa } \\
\text { dengan jalan mendemonstrasikan atau } \\
\text { lewat bahan bacaan. }\end{array}$ \\
\hline \multicolumn{2}{|l|}{ Fase 3} \\
\hline $\begin{array}{l}\text { Mengorganisasikan siswa dalam kelompok- } \\
\text { kelompok belajar }\end{array}$ & $\begin{array}{l}\text { Menjelaskan kepada siswa bagaimana } \\
\text { caranya membentuk kelompok belajar } \\
\text { dan membantu setiap kelompok agar } \\
\text { melakukan transisi secara efisien. }\end{array}$ \\
\hline \multicolumn{2}{|l|}{ Fase 4} \\
\hline Membimbing kelompok bekerja dan belajar & $\begin{array}{l}\text { Membimbing kelompok-kelompok } \\
\text { belajar pada saat mereka mengerjakan } \\
\text { tugas mereka. }\end{array}$ \\
\hline \multicolumn{2}{|l|}{ Fase 5} \\
\hline Evaluasi & $\begin{array}{l}\text { Mengevaluasi hasil belajar tentang } \\
\text { materi yang telah diajarkan atau masing- } \\
\text { masing kelompok mempresentasikan } \\
\text { hasil kerjanya. }\end{array}$ \\
\hline \multicolumn{2}{|l|}{ Fase 6} \\
\hline Memberikan penghargaan & $\begin{array}{l}\text { Mencari cara-cara untuk menghargai } \\
\text { baik upaya maupun hasil belajar individu } \\
\text { dan kelompok. }\end{array}$ \\
\hline
\end{tabular}

Ada beberapa manfaat dan kelemahan pada model pembelajaran kooperatif tipe STAD terhadap siswa yang dikemukakan Roestiyah (Makalah Pendidikan: 2011 dalam http://aadesanjaya.blogspot.com/2011/03/pembelajaran-kooperatif-tipe -stad.html). yaitu: Keuntungan model pembelajaran kooperatif tipe STAD, yaitu: (1) Dapat memberikan kesempatan kepada siswa untuk menggunakan keterampilan bertanya dan membahas suatu masalah; (2) Dapat memberikan kesempatan kepada siswa untuk lebih intensif mengdakan penyelidikan mengenai suatu masalah; (3) Dapat mengembangkan bakat kepemimpinan dan mengajarkan keterampilan berdiskusi; (4) Dapat memungkinkan guru untuk lebih memperhatikan siswa sebagai individu dan kebutuhan belajarnya; (5) Para siswa lebih aktif bergabung dalam pembelajaranmereka dan mereka lebih aktif dalam diskusi; (6) Dapat memberikan kesempatan kepada siswa untuk mengembangkan rasa menghargai, menghormati pribadi temannya dan menghargai pendapat orang lain.

Sedangkan kelemahan model pembelajaran kooperatif tipe STAD, yaitu: Kerja kelompok hanya melibatkan mereka yang mampu memimpin dan mengarahkan mereka yang kurang pandai dan kadang-kadang menuntut tempat yang berbeda dan gaya-gaya mengajar berbeda. Penmbelajaran SBK mempunyai tujuan yang sangat luas, salah satu tujuannya adalah agar siswa memiliki sikap patriotisme maupun nasionalisme juga memiliki kehalusan rasa yang bisa diaplikasikan dalam kehidupan sehari-hari. Dengan demikian penggunaan model pembelajaran kooperatif tipe STADperlu diberikan oleh guru dalam proses belajar, agar dapat mencapai hasil belajar yang lebih baik. 
Penerapan model pembelajaran kooperatif tipe STADdalam pembelajaranSBK khususnya pokok bahasan Penyajian Musikyang melibatkan siswa untuk dapat berperan aktif dengan bimbingan guru, agar peningkatan kemampuan siswa dalam menguasai materi dapat terarah lebih baik. Berdasarkan uraian di atas, dapat dirumuskan permasalahan sebagai berikut:“Apakah penggunaan model pembelajarankooperatif tipe Student Teams Achievement Division (STAD )dapat meningkatkan prestasi belajar SBK siswa kelas VIII Bsemester II SMP Negeri 7 Sukoharjo Tahun Pelajaran2017/ 2018?" Tujuan penelitian ini untuk meningkatkan prestasi belajar SBK dengan penerapan model pembelajaran kooperatif tipe STAD pada siswa kelas VIIIB SMP Negeri 7 Sukoharjo Tahun Pelajaran $2017 / 2018$.

\section{Metode Penelitian}

Penelitian ini adalah Penelitian Tindakan Kelas (PTK), atau disebut juga Classroom Action Research (CAR). Penelitian tindakan kelas merupakan suatu pencermatan terhadap kegiatan yang sengaja dimunculkan, dan terjadi dalam sebuah kelas (Arikunto, 2010: 130). Penelitian ini dilaksanakan di SMP Negeri 7 Sukoharjo. Tahap-tahap pelaksanaan kegiatan dilakukan selama kurang lebih enam bulan yaitu sejak bulan Januari sampai dengan Juni 2017. Peneliti sebagai guru mata pelajaran SBK SMP Negeri 7 Sukoharjo bertindak sebagai subjek yang melakukan tindakan kelas. Kepala Sekolah bertindak sebagai subjek yang membantu dalam perencanaan dan pengumpulan data. Subjek yang menerima tindakan adalah siswa kelas VIIIB SMP Negeri 7 Sukoharjo tahun pelajaran 2017/2018 sebanyak 32 siswa.

Adapunlangkah-langkah penelitian untuk setiap siklus pembelajaranSBKadalah sebagai berikut:

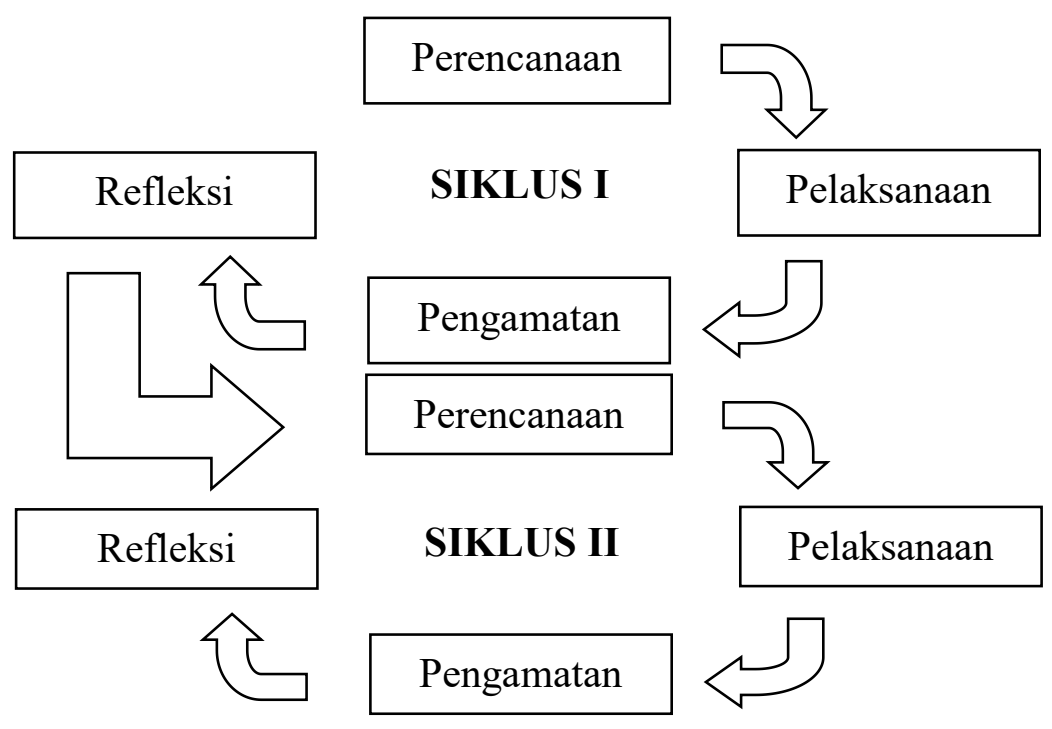

Gambar 1.Siklus Penelitian Tindakan (Arikunto, 2010:137)

Teknik pengumpulan data yang digunakan adalah: (a) Tes, observasi, dan dokumentasi. Tes adalah serentetan pertanyaan atau latihan serta alat lain yang digunakan untuk mengukur keterampilan, pengetahuan inteligensi, kemampuan atau bakat yang dimiliki oleh individu dan kelompok (Arikunto, 2010 : 193). Metode tes digunakan untuk 
memperoleh data tentang tingkat kemampuan hasil belajar SBKsiswa sebelum penelitian, selama penelitian dan setelah penelitian dilaksanakan.

Observasi yang digunakan adalah observasi sistematis, yaitu observasi yang dilakukan oleh pengamat dengan menggunakan pedoman sebagai instrumen pengamatan. Instrumen yang digunakan dalam penelitian ini adalah: lembar observasidan tes.Lembar observasi dugunakan peneliti sebagai pedoman melakukan observasi atau pengamatan guna memperoleh data yang akurat dalam pengamatan. Lembar observasi juga digunakan untuk memonitor dan mengevaluasi setiap tindakan agar kegiatan observasi tidak terlepas dari konteks permasalahan dan tujuan penelitian. Selain itu juga mempermudah peneliti dalam melakukan tanya jawabtentang bagaimana respons siswa terhadap pembelajaran yang dilaksanakan.

Tes digunakan untuk melihat seberapa besar penguasaan siswa terhadap materi yang diajarkan. Hasil tes dianalisis gunamengetahui peningkatan prestasi SBK setelah dilakukan model pembelajaran kooperatif tipe STAD. Indikator keberhasilan kinerja dalam penelitian ini adalah meningkatnya prestasi siswa yang ditunjukkan dengan meningkatnya nilai ratarata kelas, minimal menjadi 80,0 dan meningkatnya persentase ketuntasan siswa minimal $85 \%$.

\section{Hasil Penelitian}

Deskripsi data hasil penelitianyang telah dilakukan di kelas VIII BSMP Negeri 7 Sukoharjoadalah sebagai berikut. Nilai rata-rata kelas VIII B SMP Negeri 1 Bendosri Sukoharjo pada nilai ulangan harian pokok bahasan Penyajian Musiksebelum tindakan masih sangatlah rendah, yaitu hanya 70,1. Penelitian ini dilakukan dengan indikator kinerja nilai rata-rata kelas meningkat, minimal menjadi 80,0. Persentase ketuntasan siswa sebelum diadakan tidakan kelas hanya 53,1\%, dari 32 siswa yang mengikuti ulangan harian tersebut, hanya ada 17 siswayang melampaui KKM (75).

Indikator yang diharapkan peneliti, setelah tindakan kelas persentase ketuntasan siwa dapat meningkat, minimal menjadi $85 \%$. Tindakan siklus I terdapat 4 jam pelajaran $(2 \mathrm{kali}$ pertemuan), yaitu hari jumat, 16 dan 23 Februari 2018 jam ke-3 s.d 4 (pukul 08.20-09.00 dan 09.15-09.55). Materi yamg digunakan pada tindakan ini adalah Menyiapkan seni musik tradisional Nusantara untuk disajikan secara perorangan dan kelompok di kelas atau di sekolah. Dalam penyampaian materi, digunakan media atau alat bantu berupa pianika dan gitar.

Di akhir tindakan juga diberikan soal latihan. Jika dibandingkan dengan kondisi awal sebelum diadakan penelitian, nilai rata-rata, persentase ketuntasan prestasi siswa pada siklus 1 dapat dilihat dalam diagram berikut.

Tabel 2. Rekapitulasi Prestasi Belajar SBK Siswa

\begin{tabular}{lcccc}
\hline Vo & Hasil Siswa & Kondisi Awal & Siklus I & Siklus II \\
\hline 1 & Nilai rata-rata & 70,1 & 75,2 & 80 \\
\hline 2 & Siswa yang tuntas KKM & 17 siswa & 23 siswa & 29 siswa \\
& & $(53,1 \%)$ & $(71,8 \%)$ & $(90,6 \%)$ \\
\hline
\end{tabular}




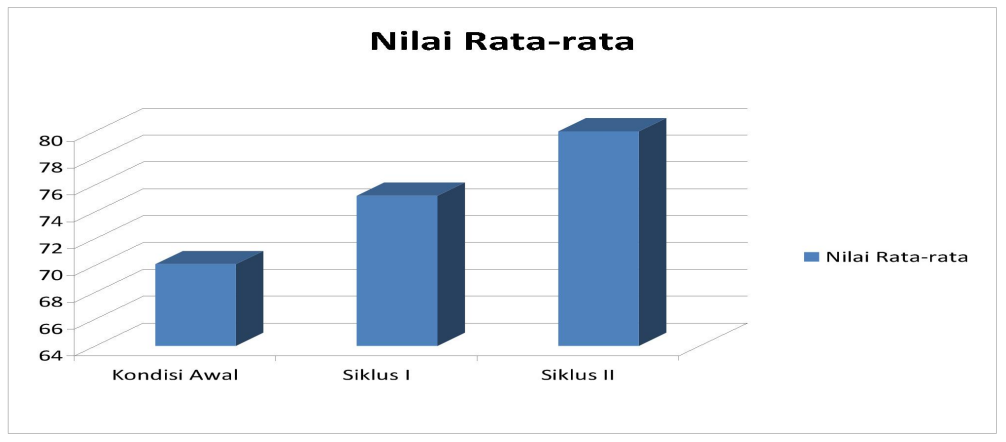

Gambar2.Diagram Rekapitulasi Rata-rata Prestasi Belajar SBK Siswa

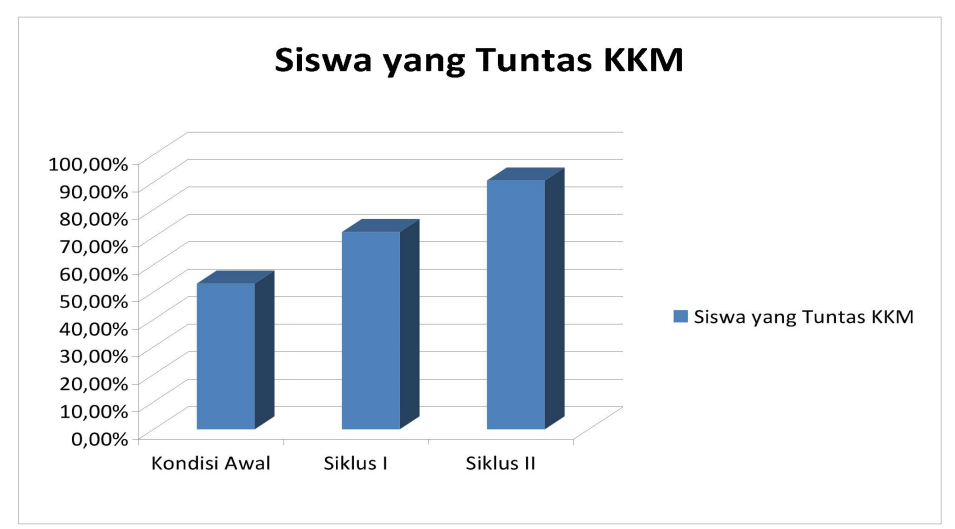

Gambar3.Diagram persentase ketuntasan siswa siklus 1

Berdasarkan hasil observasi yang dilakukan, siswa terlihat belum percaya diri saat mengerjakan soal-soal yang diberikan oleh guru.Berkaitan dengan materi yang disampaikan, Nampaknya siswa sudah memiliki gambaran mengenai masalah seni musik tradisional Nusantara untuk disajikan secara perorangan dan kelompok di kelas atau di sekolah. Setelah dilihat hasil dari latihan yang diberikan, sudah ada peningkatan jika dibandingkan dengan kondisi awal sebelum diadakan penelitian siklus 1, dari nilai rata-rata yang awalnya hanya 70,1 meningkat menjadi 75,2, tetapi masih kurang dari indikator yang diharapkan yaitu 80 . Persentase ketuntasan siswa yang awalnya hanya $53,1 \%$, pada siklus 1 dapat meningkat menjadi $71,8 \%$, tetapi masih belum memenuhi indikator kinerja yaitu sebesar $85 \%$. Tindakan siklus kedua ini terdapat 4 jam pelajaran (2 kali pertemuan), yaitu hari jumat, 2 dan 9 Maret 2018 jam ke-3 s.d 4 (pukul 08.20-09.00 dan 09.15-09.55). Pada tindakan kedua materi yang digunakan adalah Menyajikan karya seni musik tradisional Nusantara untuk disajikan secara perorangan dan kelompok di kelas atau di sekolah. Berdasarkan hasil pengamatan di dalam kelas dan hasil latihan siswa pada siklus kedua, peningkatan yang terjadi sudah sesuai indikator kinerja yang diharapkan yaitu, nilai ratarata kelas minimal 80 dan ketuntasan minimal 85\%, Berdasarkan hasil tersebut, maka penelitian sudah dapat dinyatakan selesai.

\section{Pembahasan}

Pada siklus 1dan 2, guru sudah mendorong peserta didik untuk mengaitkan materi Penyajian Musik lagu mancanegara yang disampaikan dengan konteks kehidupan nyata, sehingga siswa lebih antusias dalam mengikuti kegiatan pembelajaran.Nilai rata-rata siswa 
pada siklus 1 adalah 75,2 nilai rat-rata tersebut sudah mengalami peningkatan jika dibandingkan dengan rata-rata sebelum diadakan tindakan yang hanya 70,1 . Pada siklus 2 , nilai rata-rata siswa meningkat lagi menjadi 80.Nilai rata-rata siswa pada siklus 2 ini sudah mencapai indikator kinerja yaitu 80.00. Persentase ketuntasan siswa sejak belum diadakan penelitian sampai dengan setelah diadakan penelitian siklus 2, dapat dilihat pada tabel berikut:

Tabel 4. Persentase Ketuntasan Siswa

\begin{tabular}{lcccc}
\hline No & Hasil Siswa & Kondisi Awal & Siklus I & Siklus II \\
\hline 1 & Nilai rata-rata & 70,1 & 75,2 & 80 \\
\hline 2 & jiswa yang tuntas KKM & 17 siswa & 23 siswa & 29 siswa \\
& & $(53,1 \%)$ & $(71,8 \%)$ & $(90,6 \%)$ \\
\hline
\end{tabular}

Pada siklus 1, persentase ketuntasan siswa adalah sebesar 71,8\%, dari 32siswa, terdapat 23 siswa yang dapat mencapai atau melampaui KKM, persentase tersebut meningkat jika dibandingkan dengan kondisi awal sebelum diadakan penelitian yang hanya sebesar 53,1\%. Pada siklus 2, persentase ketuntasan siswa meningkat menjadi 90,6\%, dari 32siswa terdapat 29 siswa yang dapat mencapai KKM. Persentase ketuntasan pada siklus 2 juga sudah memenuhi indikator kerja yang hiharapkan, yaitu juga $85 \%$.

\section{Simpulan dan Saran}

Berdasarkan hasil penelitian tindakan kelas ini, maka dapat diambil kesimpulan sebagai berikut: "Modelpembelajaran kooperatif tipe STAD dapat meningkatkan prestasi belajar SBK materi Penyajian Karya Seni Musik pada siswa kelas VIII Bsemester 2 SMP Negeri 7 Sukoharjo tahun pelajaran 2017/2018. Hal ini dapat dilihat dari persentase ketuntasan belajar siswa, yaitu: sebelum tindakan 17 siswa atau 53,1\%, pada siklus I sebanyak 23 siswa atau $71,8 \%$ dan pada siklus II sebanyak 29 siswa atau 90,6\%. Sedangkan rata-rata prestasi belajar SBK siswa sebelum tindakan sebesar 70,1, pada siklus I sebesar 75,2, dan pada siklus II sebesar 80. Berdasarkan hasil penelitian tindakan kelas ini dapat diberikan saran sebagai berikut: (1) Pembelajaran kooperatif tipe STAD dapat diterapkan dalam pembelajaran SBK untuk meningkatkan keaktifan siswa kelas VIII pada materi Penyajian Karya Seni Musik. (2) Sebaiknya guru menguasai berbagai model pembelajaran agar siswa tidak merasa bosan dan enggan untuk belajar. (3) Perlu diadakan pembelajaran lebih lanjut dengan menggunakan model pembelajaran kooperatif tipe STAD pada materi lainnya.

\section{Daftar Rujukan}

Arikunto, Suharsimi. (2010). Dasar-dasar Evaluasi Pendidikan. Jakarta: Rineka Cipta. Abiet. (2011). Teori Belajar Gagne ( on line ) http // www.masbietd . com.

Fathurohman dan Sobry Sutikno. (2007). Strategi Belajar Mengajar. Bandung: PT Refika Aditama Ginting.

Hamdani. (2008). Panduan Membuat Penelitian Tindakan Kelas. Bandung: Tim Editor. Hamdani. (2011). Strategi Belajar Mengajar. Bandung: Pustaka Jaya Setia.

Supriyono Agus. (2013). Cooperatif Learning Teori dan Aplikasi PAIKEM.Yogjakarta : Pustaka Jaya.

Slavin (2009). Cooperatif Learning Teori Riset dan Paktek. Yogyakarta: Pustaka Jaya. Trianto (2009). Mendesain Model Pembelajaran Inovatif. Jakarta: PT Gramedia. Warsono dan Hariyanto. (2013). Pembelajaran Aktif Teori dan Asesmen. Bandung: 